\title{
СЕМАНТИЧНІ ОСОБЛИВОСТІ НОМІНАЦІЇ ПОЛІТИЧНОГО ОПОНЕНТА ЯК ЗАСОБУ ЙОГО ДИСКРЕДИТАЦІї
}

Барна Г. С. Семантичні особливості номінації політичного опонента як засобу його дискредитації.

У статті розглянуто семантичні особливості оцінних номенів на позначення політичних опонентів, виявлено найбільш частотні семи, що актуалізуються в процесі такої номінації, їх роль у розгортанні стратегії дискредитації об'єкта номінування.

Ключові слова: номінація, стратегія дискредитації, вербальна агресія.

Барна А. С. Семантические особенности номинации политического оппонента как средства его дискредитации.

В статье рассмотрены семантические особенности оценочных номенов для обозначения политических оппонентов, выявлены наиболее частотные семы, актуализированные в процессе такой номинации, их роль в развертывании стратеги дискредитации объекта номинирования.

Ключевые слова: номинация, стратегия дискредитации, вербальная агрессия.

Barna A. S. Semantic features of the political opponent nomination as a way of his discreditation.

The article deals with evaluative nomens semantic features to describe political opponents, identifies the most frequent semes, updated in the process of such nomination, their role in the deployment the strategy of the discreditation of a nomination object.

Key words: the nomination, the strategy to discredit, a verbal aggression.

Останні десятиліття ознаменовані підвищеним інтересом мовознавців до «номінативного напряму» в лінгвістиці. Номінація являє собою складне і багатогранне явище. Це складний феномен, при якому відбувається вербалізація розумового процесу, спрямованого на позначення навколишньої дійсності шляхом виявлення характерних ознак реалій. Вивченню цього явища присвячені праці Н. Арутюнової, В. Гака, Ф. Карташкової, О. Кубрякової, Б. Серебренникова, В. Телії, А. Уфімцевої та ін. [6, с. 423].

Провідне місце в системі номінативних засобів мови посідає непряма / вторинна номінація - спосіб називання, що для найменування інших понять використовує наявні лексичні одиниці. У результаті вторинної номінації на основі асоціацій, аналогій і конотацій утворюються мовні одиниці 3 нашаруванням додаткових значень. Вивчення непрямих номінацій, актуалізованих безпосередньо в актах комунікації, викликає науковий інтерес. Зокрема, цікавим нам видається розгляд такої проблеми в політичній комунікації.

Мова сучасної політики нагадує театр бойових дій. Через найменування виробляються і нав'язуються вигідні для суб'єкта категорії мислення, тому одним з найефективніших видів влади, за П. Бурдьє, називають «владу номінації» [цит. за: 4, с. 83]. У контексті інформаційних війн, які супроводжують політичну боротьбу, демократ може бути представлений свободолюбцем і демагогом, прихильник авторитарних методів - i «сильною рукою», $\mathrm{i}$ «душителем», правий - i традиціоналістом, і ксенофобом, лівий - і борцем за справедливість, і популістом [4, с. 108]. 
Мовні ярлики можуть бути дієвим засобом упливу на адресата. Більшість iз них містить прояви вербальної агресії, серед найтиповіших ознак якої застосування маркерів «чужості», принижувального ранжування, звинувачень у нечесності, зневажальних вульгаризмів, спрямованих на знищення опонента інвектив, демонстративна нетерпимість [4, с. 84]. Отже, номінація як вираження суб'єктивного ставлення до опонента в політичному дискурсі природно стає засобом розгортання стратегії дискредитації опонента [3].

Метою статті $є$ дослідження семантичних особливостей оцінних номенів на позначення політичних опонентів, виявлення найбільш частотних сем, що актуалізуються в процесі такої номінації.

Мовним матеріалом дослідження стала сукупність негативнооцінних найменувань опонента в сучасному українському політичному дискурсі.

Розглянемо основні семантичні відтінки в номінуванні політичних опонентів. Ключовою семою в ідентифікації політичного діяча $є$ його політична легітимність, тобто визнання його таким, що відповідає займаній посаді або виконуваним функціям. Стратегія дискредитації в політичній комунікації здійснюється, у першу чергу, через актуалізацію в номенах на позначення опонента сем «фіктивність», «нелегітимність». Засобами реалізації цих значень є використання маркерів сумнівності: лексичних (начебто православна власниця Тигрюлі, нібито православна Юлія Тимошенко, так звані націонал патріоти від БЮТ $i$ НУ, доморощена Жанна д’Арк, самопроголошена лідерка опозиціï), семантико-пунктуаційних («дбайлива» матуся Юля, «гнані і знедолені» опозиціонери, лідерка «воїнства світла», «набожнна» Тимоченко, лідер «партії європейського типу», «опозиціонерка» Тимошенко, «полум'яний революціонер» Юрій Луценкко, помаранчева «героїня», ия «богиня», «християнка» Тимошенко, ия, прости Господи, «християнка») оказіональних словотворчих (багіня, поцтріоти).

Семи «недієздатність», «ущербність» актуалізовано такими номенами: «помаранчеві» крикуни («Напад націонал-ідіотизму, або Лікнеп для «помаранчевих» крикунів»), довершена політична клоунеса, інваліди («стара засмальцььована колода «інвалідів» української політики») політичні «карлики», помаранчево-бютівські пустомелі, «бджсоловод-імпотент», носії «синдрому набутого майдаунізму», «оранжисти», щзо відморозили собі мізки, Януковоч ( (у переносному значенні), Свнухович ( $\leftarrow$ євнух + Янукович).

Важливими i затребуваними для реалізації стратегії дискредитації політичного опонента природно є семи «брехливість», «нещирість»: негідники $i$ брехуни («Негідникам $і$ брехунам не місие в уряді»), Брехуля, брехЮльки, Пиздюля, партія брехіонів, майстер політичного шоу (про Ю. Тимошенко), жертви-симулянти, біло-сердечні фарисеї. Ці відтінки значень актуалізовано також в оказіонально трансформованих варіантах прізвищ політиків: Тягнивбік, 
Тягниукраӥнувсраку, Хєрвам (таким чином заявляється, що презентовані наміри осіб не відповідають реальним), Фіртющенко (вказується на приховуваний бізнес-зв’ язок В. Ющенка і Д. Фірташа).

Близькою до попередніх є сема «шахрайство», що представлена оказіональними лексемами: Тимошенниця (від рос. «мошенница»), пані Жулья (від рос. «жульё») і паліндромом вор Азаров.

Важливими семантичними аспектами негативної презентації політичного опонента $\epsilon$ також семи «продажність», «керованість» (кремлядь, депутани, фрашистські прихвосні, Тягнибакс); «зрада» (професійний кидала (про Ю. Тимошенко), псевдо помаранчева союзниця, Іудщенко, Юдщзенко), «фашизм» (нашисти, послідовниця Адольфа Алоїзовича), «єврейські корені» (Жидюля, Хазаров).

Актуалізацію значення «зв'язок із нечистим» не можна назвати типовою для політичної комунікації, але в українському політичному дискурсі така сема певним чином представлена: берегиня окультистів, богиня Хао́су, духовна блудниия, обтяжена владою, але обділена християнськими чеснотами «берегиня» розмаїтої політичной $\check{u}$ окультистської нечисті, послідовниця бісівського культу поклоніння змію/дияволу/сатані, сектантка й сатаністка, «вампір», жінка з косою, «політична вдова», мадам Богомерзька, Богохульська.

Більшість наведених вище негативних лексичних значень актуалізується й тоді, коли об’єктом номінування стають команди політиків-опонентів, їх прихильники і послідовники. На позначення групових назв опонентів знаходимо такі лексеми, основні й додаткові значення яких підкреслюють недієздатність, дефектність, деструктивність цих утворень - «секта», «стадо», «орда», «хунта», «болото», «кліка», «камарилья»: релігійна секта, неорелігійна організація сектантського типу, сектантського типу структура, Свідки Янукови, стадо «Батьківщчини», помаранчеве неоначистське стадо, орда, хунта, монолітне болото, або ЗАТ «БЮТ», Тимошенко та ї̈ кліка, Ющзенко та його камарилья. Інші номени цієї групи засвідчують такі додаткові значення: янучари, янучарня (актуалізована сема «зрада»), юльки, юлевіри (наївність), жульфани, юлісти (зомбованість), юлеботи (примітивність), юлькануті, юлегофрени (психічні відхилення).

Демонстративне відсторонення i відчуження від опонента супроводжується використанням інвективної лексики зі звинувачувальною тональністю. У більшості випадків мають місце прямі форми мовленнєвої агресіі, виражені тактиками образи, зневаги тощо. Тактика образи розгортається, зокрема, за участю таких номінацій: бандерівські недобитки, інтелектуальні недомірки, неонащистські виродки, мудак («Ющенко - ТАК! Янукович - ...ДАК!»), урод («Одна Украӥна - єдиний урод»), мудачник («Звільнять Табачника - призначать іншого мудачника»), ВО «Сволота», ПРидурки, Бидлозек Пьодорич, Бидлюкович, ющльопки, убютки (від

С Г. С. Барна, 2011. 
рос. «ушлепки», «ублюдки»), нужник (від рос. «нужник» (туалет): 1 - член партії або прихильник НУ; 2 - В. Литвин (слоган виборчої кампанії «Країні потрібен Литвин»); Холерій Ворошковський (гра слів). Для дискредитації опонентів у політичний дискурс уводиться навіть вульгарно-непристойна лексика: Припиздент, Яхуйович тощо.

Тактика зневаги знаходить відображення в лексиці зі значенням дрібноти: бютішки, ющенята, у модифікованому написанні прізвищ політиків, назв партій, що додатково актуалізує певні семи Йуля, Ющ, Прищ, Ю-Щенок (від рос. «щенок»), Тібіпка, Чивокуня («Янукович» справа наліво), партія районів.

У межах розгортання стратегії дискредитації актуалізуються також оказіональні номени, що засвідчують акцент на образах фізіологічного плану: Вітя Анусович, Вонющенко, Блювотословська, Каловонюк, вагіня, ригоанали, адмінівсрачія президента.

Особливу групу номінацій опонента становлять прецедентні номени, декодування яких потребує певних фонових знань і можливе лише за умови обізнаності про певні події чи ситуації. Ця група постійно поповнює свій склад синхронно з політичними подіями, що відбуваються. Значну частку таких номенів становлять оказіональні композити 3 яскраво вираженим пейоративним і експресивнооцінним компонентом у структурі семантики слова. Наприклад: профффесор, Віктор Ффедорович (прецедент - анкета-автобіографія $з$ помилками); проффффесор (прецедент - намір присудити В.Януковичу звання почесного професора МДУ ім. Ломоносова під час візиту до РФ); Конфузій $(\leftarrow$ Конфуцій + конфуз; прецедент - постійні обмовки в мовленні В. Януковича); XАMдидат в Президенти $(\leftarrow$ Хам + кандидат; фонове знання - тюремне прізвисько «Хам»); Йожик в тумані (прецедент - В. Янукович не зміг вилетіти до Польщі та кількох українських міст через туман); миздобул (на позначення В. Ющенка; фонові знання - основний слоган виборчої кампанії «Ми здобули!») i похідні: миздобол (утворено шляхом злиття основ із обсценною лексемою), миздобулофіли (прихильники миздобула); медофіли (фонові знання - В. Ющенко шанувальник бджолярства); глечканутий пчилавод (на позначення В. Ющенка; імітація грузинського акценту президента Грузії М. Саакашвілі: «Гаваріль тєбє, начинай реформи, глечканутий пчилавод»; фонові знання - захоплення глечиками i бджолами); всіхпочуй (на позначення В. Януковича, за аналогією 3 «миздобул»; фонові знання - основний слоган виборчої кампанії «Почую кожного...»); Підрахуй (С. Ківалов у період головування в ЦВК, звинувачений у фальсифікації результатів виборів); політик-франтаст (про Ю. Тимошенко; прецедент - запуск інтернет-проектів «Ідеальна країна» та «Країна 3-го тисячоліття»); вона (субстантивований займенник: «Наша ВОНА наближення світової економічної кризи впритул не бачила»; фонові знання - серія рекламних роликів «Вони балакають, вона - працює» 3 
модифікаціями); «дапашліви» (на позначення М. Азарова; прецедент однойменна відповідь депутатам); кровосісь (про М. Азарова; обмовка «кровосісі» замість «кровососи», розтиражована в інтернеті), варіант кровосісядапашліви; козлокапусний гречкун (М. Азаров) тощо.

Отже, найменування опонента в сучасній українській політичній мові природно засвідчують превалювання негативнооцінних конотацій. Це відповідає загальній лінгвістичній тенденції переважання пейоративних оцінок над меліоративними. Основними семами в лексичному значенні номенів, що вказують на політичних опонентів i актуалізуються в результаті непрямої номінації, є семи зрада, обман, шахрайство, продажність, нездатність, фіктивність тощо. Стратегія дискредитації опонента розгортається на фоні застосування обсценної лексики, інвективних ярликів, що послідовно утримує політичний дискурс у руслі опозиції «свій-чужий». Висока концентрація негативнооцінної лексики стирає грань між дозволеним і недозволеним у політичній узаємодії.

Література

1. Безрукова В. В. Интенсификация и интенсификаторы в языке и речи: на материале английского языка: автореф. дис. на соискание науч. степени канд. филол. наук: спец. 10.02 .04 «Германские языки» / Вера Викторовна Безрукова. - Воронеж, 2004. - 23 с.

2. Вардезлашвили Ж. А. К вопросу о толковании термина «номинация» в лингвистических исследованиях / Ж. А. Вардзелашвили // Славистика в Грузии. - Вып. 1. - Тб., 2000. - С. 62-68.

3. Захарченко Н. Стратегія «дискредитації опонента» в полемічних трактатах Мартіна Лютера / Наталія Захарченко // Наукові записки. - Серія: філологічні науки. - Вип. 89 (1). - С. 421-424.

4. Нагорна Л. Політична мова і мовна політика / Лариса Нагорна. - К. : Світогляд, 2005. - 315 с.

5. Языковая номинация (Виды наименований) / [отв. ред. Б. А. Серебренников, А. А. Уфимцева]. М. : Наука, 1977. - 359 с.

6. Хмара Г. Номінація як об'єкт лінгвістичних досліджень: історія становлення і сучасність / Галина Хмара // Вісник ЛНУ. - Серія: філологічні науки. - 2004. - Вип. 34. - Ч. 1. - С. $423-427$.

\section{Список використаних джерел}

1. Матеріали офіційних сайтів політичних партій (ПР, БЮТ, КПУ, ПСПУ, ВО «Свобода»).

2. Мовний контент політичних сайтів http://durdom.in.ua та http://www.pravda.com.ua.

3. Ротаєнко О. То хто ж «ВОНА» така? / Олександр Ротаєнко. - К., 2010.

4. Чобіт Д. Монолітне болото, або ЗАТ «БЮТ» / Дмитро Чобіт. - [3-тє вид., доп.]. - Броди : Просвіта, 2006.

Стаття надійшла до редакції 20.10.2011 p. 